\title{
Performance of Sound Insulation in Buildings A Case Study
}

\author{
Marcus Vinícius Manfrin de Oliveira Filho and Paulo Henrique Trombetta Zannin \\ Federal University of Paraná, Brazil
}

(Received 6 February 2015; accepted 3 May 2016)

The purpose of this study is to recognize usual facade sound insulation problems that affect a construction's acoustical quality by measuring the facade's sound insulation. Thirteen different situations were evaluated through in situ measurements in Curitiba, Brazil. By measuring buildings in different locations with constructive materials and different designs, this research found that the performance of the majority of evaluated facades did not reach the minimum proposed by both Brazilian and Portuguese standards. These results indicate that the sound insulation quality in Brazilian buildings is low and is mainly due to constructive imperfections and the use of materials with unfavorable acoustical properties.

\section{INTRODUCTION}

Recent studies have found that, like other Brazilian metropolises, Curitiba is acoustically polluted. ${ }^{1-7}$ The solution to this environmental problem involves control by means of technical, political, and educational actions. One of the main tools available to ensure adequate sound pressure levels inside buildings is the sound insulation of their facades. Like so many other branches of engineering, sound insulation design requires dedicated study to reach established goals and to correct nonconforming situations by taking into account the management of various resources (e.g. financial, time, labor, materials, etc.).

Previous studies suggest builders were negligent with the acoustical quality of Brazil's building facades. Based on statistical surveys, Jobim claimed that the lack of acoustic comfort is a major source of dissatisfaction among home owners. ${ }^{8}$ According to Queiroz and Viveiros, the quality of sound insulation of frontal facades in Brazil declined significantly between 1968 and 2005. ${ }^{9}$ All the homes assessed by Ferreira and Zannin in Curitiba presented sound insulation values that did not meet the German standard DIN 4.109 "Schallschutz im Hochbau". ${ }^{10,11}$

Thirteen different situations of facades were evaluated in situ in Curitiba, state of Paraná, according to the parameter of weighted standardized level difference $-D_{2 m, n T, w}$. The results were compared with the Brazilian standard NBR 15.575 "Edificações habitacionais Desempenho" and Portugal's Building Acoustics Regulations - RRAE "Regulamento de Requisitos Acústicos de Edificações". ${ }^{12,13}$ Gaps of approximately $0.5 \mathrm{~cm}$ in length were left deliberately in three facades in order to study their effect on the sound insulation of the buildings.

\section{METHODOLOGY}

Sound insulation measurements were taken in thirteen situations at different building facades (e.g. apartments, homes and classrooms) in various parts of Curitiba. Several situations were addressed and took different building materials into account.

The measurements were taken according to the global method described in the standard ISO 140-5 "Acoustics Measurement of sound insulation in buildings and of building el- ements". ${ }^{14}$ The loudspeaker and traffic noise methods were used according to the most suitable one for each situation. Internal sound sources (e.g. neighbors and household appliances)were not considered, since measurements were taken in quiet conditions. The measured parameter was the standardized level difference $D_{2 m, n T}$, in the 100 to $3150 \mathrm{~Hz}$ frequency range. Then, the procedure described in the standard ISO 7171 "Acoustic Rating of sound insulation in buildings and of building elements Part 1: Airborne sound insulation" was used, which allowed the team to obtain a single value for sound insulation performance (i.e. the weighted standardized level difference), $D_{2 m, n T, w}{ }^{15}$

This single value represents the result of the measurement of acoustic parameters taken in octave or one-third octave frequency bands. This value was used as the criterion to compare the measured values and those established by Brazilian and Portuguese standards (NBR 15.575 and RRAE, respectively).

The standardized level difference, $D_{2 m, n T}$, is given by: ${ }^{14}$

$$
D_{2 m, n T}=L_{1,2 m}-L_{2}+10 \log \left(\frac{T}{T_{o}}\right) ;
$$

where:

$D_{2 m, n T}$ - standardized level difference measured $2 \mathrm{~m}$ away from the facade, $\mathrm{dB}$;

$L_{1,2 m}$ - external sound pressure level $2 \mathrm{~m}$ away from the facade, $\mathrm{dB}$;

$L_{2}$ - indoor average sound pressure level, $\mathrm{dB}$;

$T$ - indoor average reverberation time, s;

$T_{o}-$ indoor reference reverberation time value, $=0,5 \mathrm{~s}, \mathrm{~s}$;

The parameters $L_{1,2 m}$ and $L_{2}$ were measured simultaneously by using two microphones, a dual channel adapter, and a flat cable. This flat cable could be passed through an element that separates the facade (door or window) even when it was closed. This was necessary because if a cylindrical cable was used, a crack would have had to be left open in the separating element, which would have impair the accuracy of the measurement of the sound insulation, thus underestimating its levels. ${ }^{14}$ All data was collected in the afternoon over the course of several days and, although the equipment set up time was long, each measurement lasted for only a few seconds. 


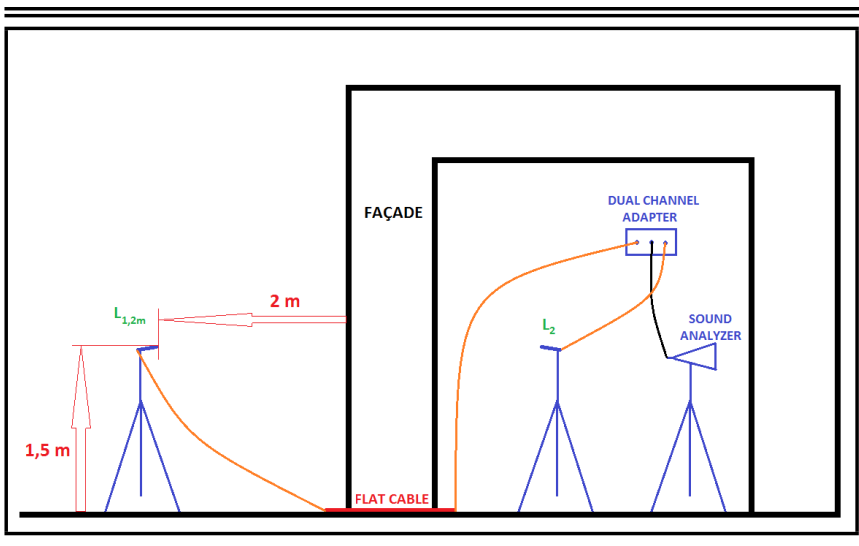

Figure 1. The measurement scheme.

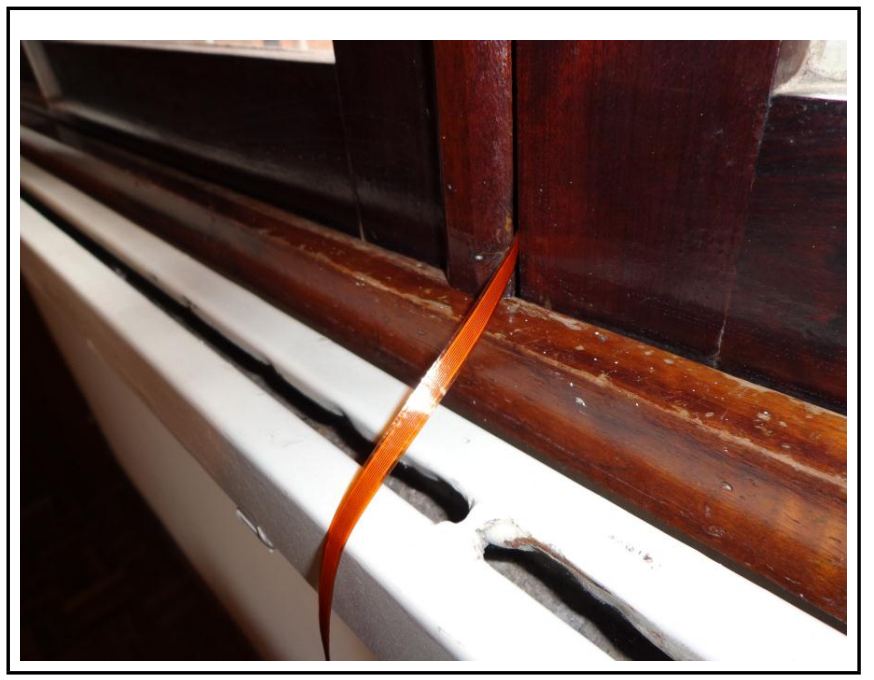

Figure 2. Flat cable through a window.

Reverberation time, a parameter required for the calculation of the weighted standardized level difference, was measured as specified by ISO 354 "Measurement of sound absorption in a reverberation room". ${ }^{16}$ This standard regulated all of the procedures needed for the determination of this parameter by the interrupted noise method.

All measurements were taken with Class 1 Brüel \& Kjaer equipment, which included microphones, cables, and a sound analyzer. The microphones were externally calibrated with a caliper before each measurement, as was recommended in the user manual. ${ }^{17}$

\subsection{Regulatory Aspects}

The Brazilian standard NBR 15.575-4 provided methods and values for the performance of buildings in various branches. ${ }^{12}$ With regard to acoustic performance, the Brazilian standard NBR 15.575-4 presented a table containing the minimum allowable values for the sound insulation of facades, depending on the location of the home.

The RRAE (Portugal's Building Acoustics Regulations) established minimum values for the weighted standardized level difference, which were reached according to the type and zoning of buildings.13 The General Regulation on Noise (RGR) was consulted to determine the zoning of each building. This law established the zoning of urban areas according to land use. ${ }^{18}$

Note that foreign standards had to be used to assess the acoustic quality of buildings in Brazil, since the Brazilian stan-

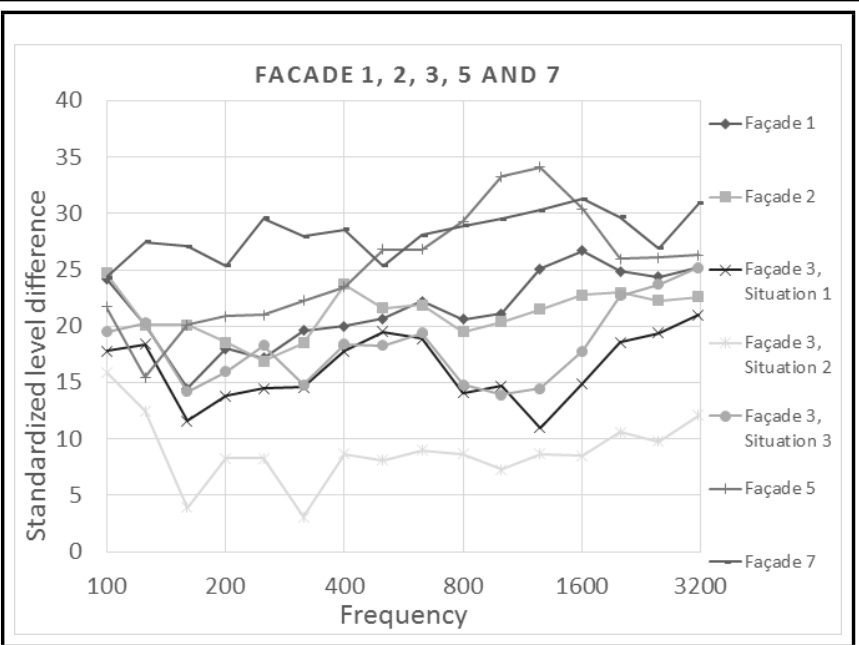

Figure 3. Standardized level difference for facades 1, 2, 3, 5 and 7.

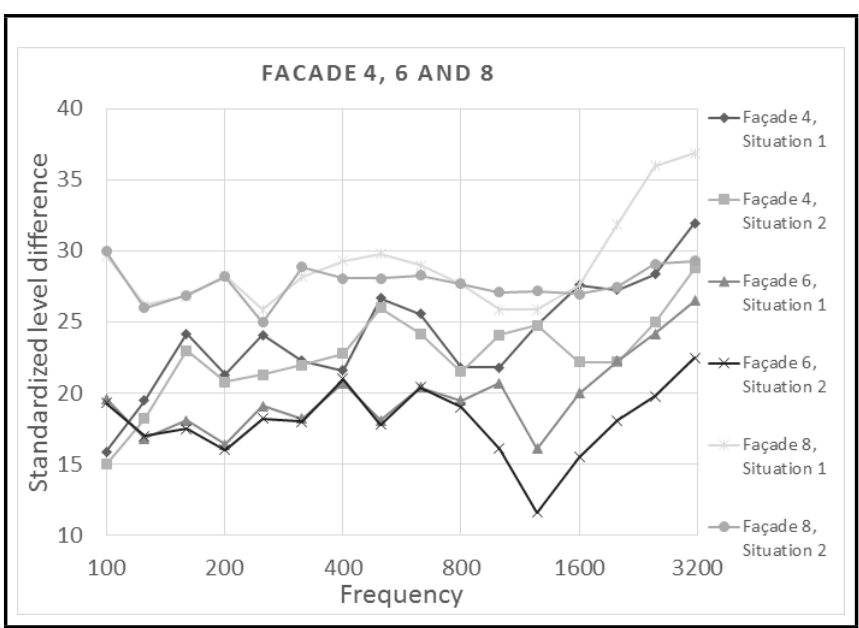

Figure 4. Standardized level difference for facades 4, 6 and 8.

dard NBR 15.575 covers only acoustic requirements for bedrooms. Brazil has no valid regulation on sound insulation requirements for hospitals, classrooms, offices, churches, or other types of buildings.

The Portuguese regulation was chosen because it uses the same parameter of comparison for the sound insulation of facades as that of the NBR 15.575-4 standard - the weighted standardized level difference, $D_{2 m, n T, w}$. According to both the Brazilian and the Portuguese standards, this parameter established minimum values for each case are shown in section 3.7.

\section{RESULTS AND DISCUSSION}

Table 1 shows the room types, location, and building aspects of the eight studied facades. Figures 3 and 4 show the measured standardized level difference curve for all the situations presented in this study. Other measurement relevant descriptions - measured values, photographs, and pertinent comments - are given in the following sections. The global loudspeaker method was used in Facades 1 to 7 . Measurements on Facade 8 were taken considering the road traffic noise (other noise sources were negligible in the area) by using the global traffic noise method. ${ }^{14}$ 
M. V. M. Filho, et al.: PERFORMANCE OF SOUND INSULATION IN BUILDINGS - A CASE STUDY

\begin{tabular}{|c|c|c|c|c|}
\hline Facade & Room type & Location (neighborhood) & Facade constitution & Materials thickness \\
\hline 1 & bedroom & Cristo Rei & $\begin{array}{c}\text { masonry walls }-11.68 \mathrm{~m}^{2} \\
\text { plain glass sliding windows }-5.6 \mathrm{~m}^{2} \\
\text { total }-17.28 \mathrm{~m}^{2}\end{array}$ & $\begin{array}{c}\text { walls }-12.5 \mathrm{~cm} \\
\text { plain glass }-6 \mathrm{~mm}\end{array}$ \\
\hline 2 & bedroom & Cristo Rei & $\begin{array}{c}\text { masonry walls }-6.89 \mathrm{~m}^{2} \\
\text { plain glass sliding windows }-2.8 \mathrm{~m}^{2} \\
\text { total }-9.69 \mathrm{~m}^{2}\end{array}$ & $\begin{array}{c}\text { walls }-12.5 \mathrm{~cm} \\
\text { plain glass }-6 \mathrm{~mm}\end{array}$ \\
\hline 3 & bedroom & Uberaba & $\begin{array}{c}\text { masonry walls }-5.07 \mathrm{~m}^{2} \\
\text { plain glass / light metal shutter sliding door }-3.18 \mathrm{~m}^{2} \\
\text { total }-8.25 \mathrm{~m}^{2}\end{array}$ & $\begin{array}{c}\text { walls }-12.5 \mathrm{~cm} \\
\text { plain glass }-6 \mathrm{~mm} \\
\text { light metal shutter }-3 \mathrm{~mm}\end{array}$ \\
\hline 4 & living room & Uberaba & $\begin{array}{l}\text { masonry walls }-5.32 \mathrm{~m}^{2} \\
\text { sliding glass door }-4.91 \mathrm{~m}^{2} \\
\text { total }-10.23 \mathrm{~m}^{2}\end{array}$ & $\begin{array}{c}\text { walls }-12.5 \mathrm{~cm} \\
\text { plain glass }-6 \mathrm{~mm}\end{array}$ \\
\hline 5 & classroom & Jardim das Américas & $\begin{array}{c}\text { masonry walls }-17.36 \mathrm{~m}^{2} \\
\text { plain glass windows }-20.5 \mathrm{~m}^{2} \\
\text { total }-37.86 \mathrm{~m}^{2}\end{array}$ & $\begin{array}{c}\text { walls }-25 \mathrm{~cm} \\
\text { plain glass }-8 \mathrm{~mm}\end{array}$ \\
\hline 6 & $2^{\text {nd }}$ floor bedroom & Uberaba & $\begin{array}{c}\text { masonry walls }-5.95 \mathrm{~m}^{2} \\
\text { plain glass sliding door }-3.18 \mathrm{~m}^{2} \\
\text { total }-9.13 \mathrm{~m}^{2}\end{array}$ & $\begin{array}{l}\text { walls }-12.5 \mathrm{~cm} \\
\text { plain glass }-6 \mathrm{~mm}\end{array}$ \\
\hline 7 & living room & Uberaba & $\begin{array}{l}\text { brick walls }-4.05 \mathrm{~m}^{2} \\
\text { stained glass extending to the second floor } 2.06 \mathrm{~m}^{2} \\
\text { heavy wooden door } 2.09 \mathrm{~m}^{2}\end{array}$ & $\begin{array}{l}\text { brick walls }-12.5 \mathrm{~cm} \\
\text { wooden door }-3.2 \mathrm{~cm}\end{array}$ \\
\hline 8 & $6^{\text {th }}$ floor bedroom & Downtown & $\begin{array}{c}\text { total } 8.20 \mathrm{~m}^{2} \\
\text { masonry walls }-8.22 \mathrm{~m}^{2} \\
\text { double glazed acoustic window }-2.7 \mathrm{~m}^{2} \\
\text { total }-10.92 \mathrm{~m}^{2}\end{array}$ & $\begin{array}{c}\text { stained glass }-8 \mathrm{~mm} \\
\text { walls }-12.5 \mathrm{~cm} \\
\text { two } 4 \mathrm{~mm} \text { thick glass layers }\end{array}$ \\
\hline
\end{tabular}

\subsection{Facade 1}

A value of $23 \mathrm{~dB}$ for the weighted standardized level difference was determined from this measurement, thus indicating that Facade 1 did not meet the minimum $25 \mathrm{~dB}$ requirement stipulated by the Brazilian standard NBR 15.575-4 for this case.

Because the facade area was made of single-layered plain glasses, the levels of sound insulation were decreased in the 500 to $1500 \mathrm{~Hz}$ frequency range approximately, when compared to the shifted reference values curve utilized to calculate the weighted standardized level difference. ${ }^{15,19}$ In addition, the sliding window did not have an appropriate sealing, leaving gaps between the metal structures that sustained the glasses. These constructive imperfections were caused due to the lack of the window maintenance and to the use of non-standard materials.

\subsection{Facade 2}

The sliding windows of Facade 2 showed gaps between the wooden window frames and the glass panes, as illustrated in Fig. 5. This type of crack was quite common and often found in Brazilian buildings. A value of $22 \mathrm{~dB}$ for the weighted standardized level difference was determined from this measurement, thus indicating that Facade 2 does not meet the minimum $25 \mathrm{~dB}$ requirement stipulated by the Brazilian standard for this case.

Facade 2 presented a poor sound insulation performance in the higher frequencies when compared to the shifted reference curve. The same behavior was found in Facades 4, 6, and 8, in which openings of $0.5 \mathrm{~cm}$ were intentionally left, as shown in section 3.4. This suggests that gaps of this magnitude affect the facade sound insulation levels, especially in this frequency range. The cracks found in Facade 2 were consequences of the use of non-standardized materials, which had unfavorable acoustic properties.

\subsection{Facade 3}

Facade 3 was evaluated in three different situations:

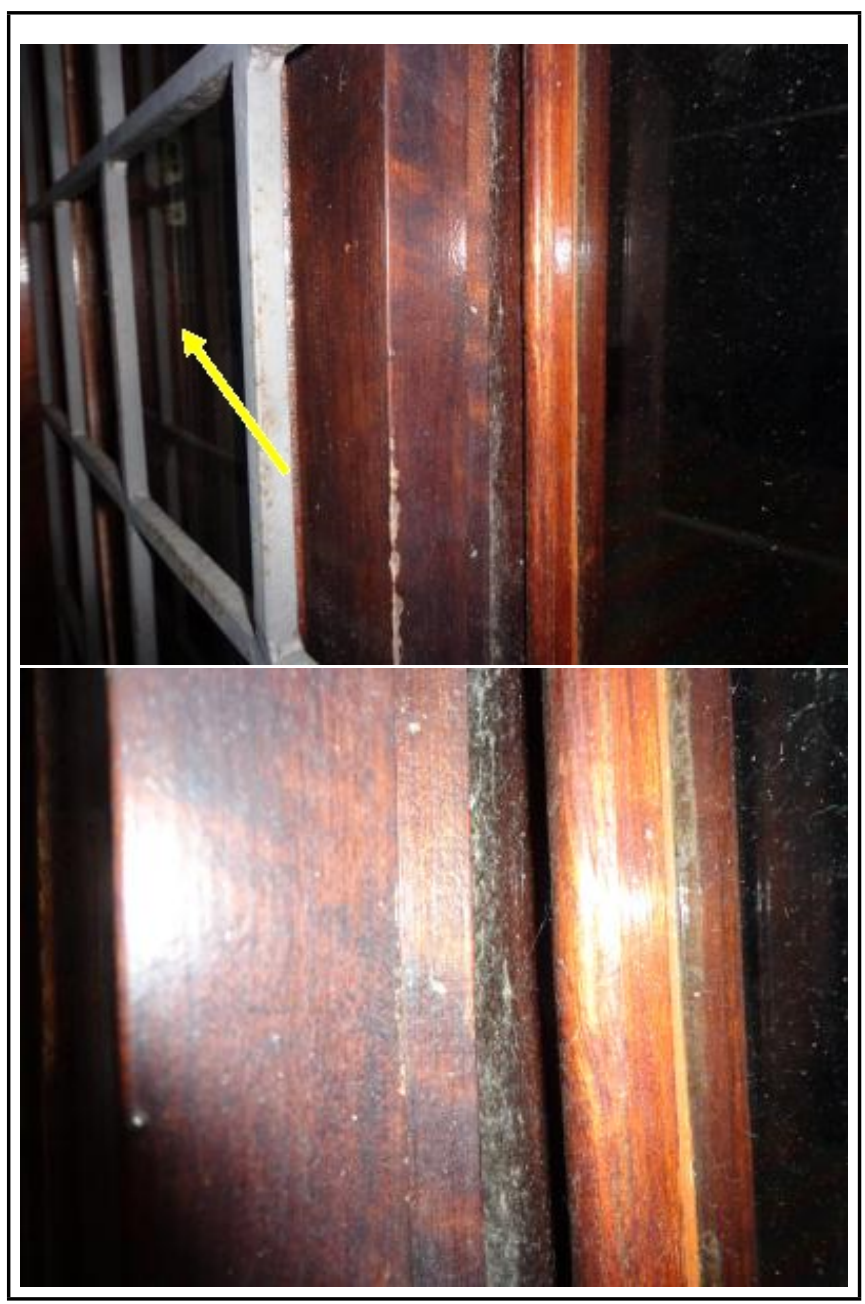

Figure 5. Gaps in the window frames of facade 2. 


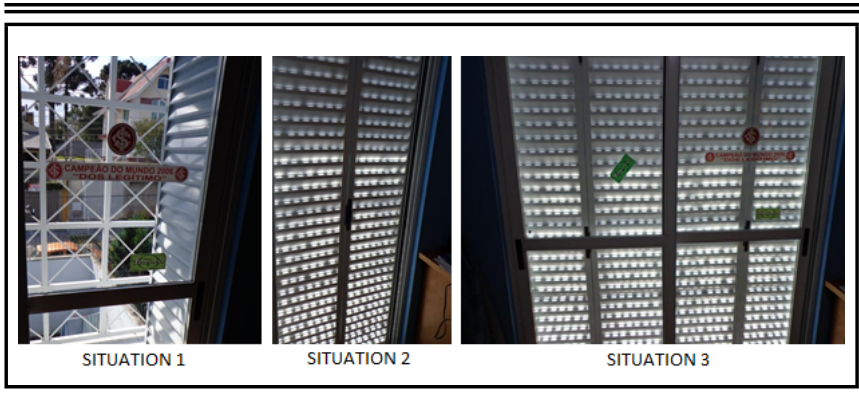

Figure 6. Facade 3 in the three different situations.

Table 2. The measurements of facade 3 .

\begin{tabular}{||c|c|}
\hline Situation & $D_{l s, 2 m, n T, w}[\mathrm{~dB}]$ \\
\hline 1 & 17 \\
\hline 2 & 9 \\
\hline 3 & 19 \\
\hline \multicolumn{2}{|c|}{ SOURCE: The authors (2013). }
\end{tabular}

1. Situation 1 - Only the glass door closed (metal shutters open);

2. Situation 2 - Only the metal shutters closed (glass door open);

3. Situation $2-$ Metal shutters and glass door both closed.

Fig. 6 illustrates the evaluated situations.

The results of the measurements of Facade 3 are listed in Table 2.

As can be seen, Facade 3 does not meet the minimum $25 \mathrm{~dB}$ requirement set by the Brazilian standard in any of the three measured situations. The contribution of the metal shutters to the sound insulation combined with that of the glass door is $2 \mathrm{~dB}$ for the weighted standardized level difference (from 17 to $19 \mathrm{~dB}$ ).

Since there are no gaps in Facade 3, the results under the minimum value established by the Brazilian Standard are due to the use of materials with unfavorable acoustic properties, such as light metals and a single layered plain glass door. Similarly to Facade 1, Facade 3 presents low sound insulation levels in the 500 to $1500 \mathrm{~Hz}$ frequency range approximately, when compared to those found in the shifted reference values curve described in ISO 717. ${ }^{15}$ These weak points were caused by the use of single-layered plain glasses that have had a worse performance than the $10 \mathrm{~cm}$ thick masonry walls. ${ }^{19}$

\subsection{Facade 4, 6, 8}

Facades 4, 6, and 8 were evaluated in two different situations:

1. Situation 1 - Glass door / window completely closed;

2. Situation $2-$ Glass door / window open $0.5 \mathrm{~cm}$; the opening was left intentionally to simulate gaps in the order of magnitude commonly found in Brazilian buildings.

Figure 7 illustrates Situations 1 and 2.

The values determined for the weighted standardized level difference of Facades 4, 6, and 8 in Situations 1 and 2 are shown in Table 3.

Facade 4 sound insulation levels are below the $28 \mathrm{~dB}$ minimum value recommended by Portuguese standards. The Brazilian standard does not provide for sound insulation levels for rooms other than bedrooms. There were difficulties on

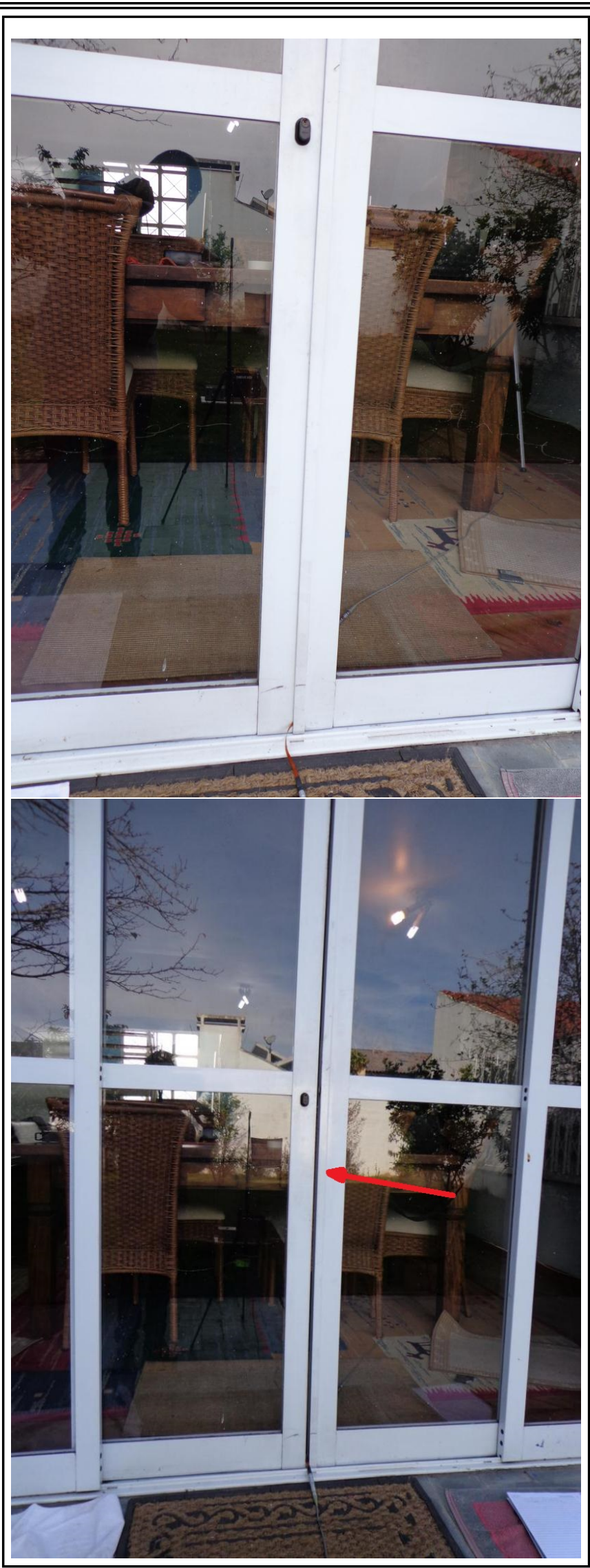

Figure 7. Facade 4 sliding glass door closed, and with an $0.5 \mathrm{~cm}$ opening situations 1 and 2 .

opening and closing the door of this facade due to the friction between the lower part of the door and the metal sliding guide. This constructive imperfection, which could also cre- 
Table 3. Depth of crack for different crack widths and aspect ratios.

\begin{tabular}{|c|c|c|c|c|}
\hline & & $\begin{array}{l}\text { Measured } D_{2 m, n T, w} * \\
{[\mathrm{~dB}]}\end{array}$ & $\begin{array}{l}\text { Minimum } D_{2 m, n T, w} \\
\text { according to NBR } 15.575-4[\mathrm{~dB}]\end{array}$ & $\begin{array}{l}\text { Minimum } D_{2 m, n T, w} \\
\text { according to Portugal's RRAE [dB] }\end{array}$ \\
\hline Facade 4 (living room) & $\begin{array}{l}\text { Situation } 1 \\
\text { Situation } 2\end{array}$ & $\begin{array}{l}26 \\
24\end{array}$ & not specified & 28 \\
\hline Facade 6 (bedroom) & $\begin{array}{l}\text { Situation } 1 \\
\text { Situation } 2\end{array}$ & $\begin{array}{l}21 \\
18\end{array}$ & 25 & 28 \\
\hline Facade 8 (bedroom) & $\begin{array}{l}\text { Situation } 1 \\
\text { Situation } 2\end{array}$ & $\begin{array}{l}30 \\
28\end{array}$ & 30 & 33 \\
\hline
\end{tabular}

SOURCE: The authors (2013)

ate gaps, was explained by the low-quality workmanship and a lack of maintenance. Additionally, the constructive material, which was a single layered pain glass sliding door, did not offer a high performance sound insulation, which explained the results under the minimum established by the Portuguese standard. ${ }^{19}$

The values determined for the weighted standardized level difference of Facade 6 were below the minimum values recommended by both the Brazilian and the Portuguese standards. There were found no gaps during the measurements of this facade. The results under the minimum established by the standards were due to the use of materials with unfavorable acoustic properties, such as light metals and a single layered plain glass door.

The value determined for the weighted standardized level difference for Facade 8 in situation 1 was $D_{t r, 2 m, n T, w}=$ $30 \mathrm{~dB}$. Thus, this value lies within the permissible minimum threshold according to the Brazilian standard, but did not attend the Portuguese standard requirements. The double layered glass acoustic window showed a remarkably determining performance in this case. Without it (or with the window open), the sensation of acoustic discomfort in the bedroom was heightened due to the heavy vehicle traffic, disturbing simple daily activities, such as sleeping or reading.

Since Facade 8 was from a bedroom located on the $6^{\text {th }}$ floor of an apartment building, the measurement of the $L_{1,2 m}$ level was taken with the external microphone attached to a fishing rod suspended on the balcony of an adjoining room. The procedure, illustrated in Fig. 8, allowed the microphone to be held $2 \mathrm{~m}$ away from the facade. ${ }^{14,20}$

In Table 3, Facades 4 and 8 present a decrease of $2 \mathrm{~dB}$ and Facade 6 presents a decrease of $3 \mathrm{~dB}$ over the weighted standardized level difference between situations 1 and 2, when a gap of $0.5 \mathrm{~cm}$ was left open deliberately. The test with the open gap confirmed the effect perceived subjectively: the lack of sealing in an element separating two environments deteriorates the quality of sound insulation between them.

In addition, it was noted that the gaps affected the standardized level difference curve in a similar way for Facades 4, 6, and 8 . Sound insulation level curves suffered a significant decrease in high frequencies. Facade 4, for example, had a decrease of $5.4 \mathrm{~dB}$ in the $1600 \mathrm{~Hz}$ frequency band when compared to Situations 1 and 2; Facade 6 had a $4.6 \mathrm{~dB}$ decrease in the $1000 \mathrm{~Hz}$ frequency band; and Facade 8 had a $6.9 \mathrm{~dB}$ decrease in the $2500 \mathrm{~Hz}$ frequency band. The levels in frequencies lower than $1000 \mathrm{~Hz}$ remained close in both Situations 1 and 2, as shown in Fig. 4.

\subsection{Facade 5}

Facade 5 was from classroom PG-06 located on the campus of the Polytechnic Center of the Federal University of Paraná UFPR. The measurement was taken while the classroom was unoccupied. The measurements showed that Facade 5 provides acoustic insulation of $D_{l s, 2 m, n T, w}=28 \mathrm{~dB}$, indicating that

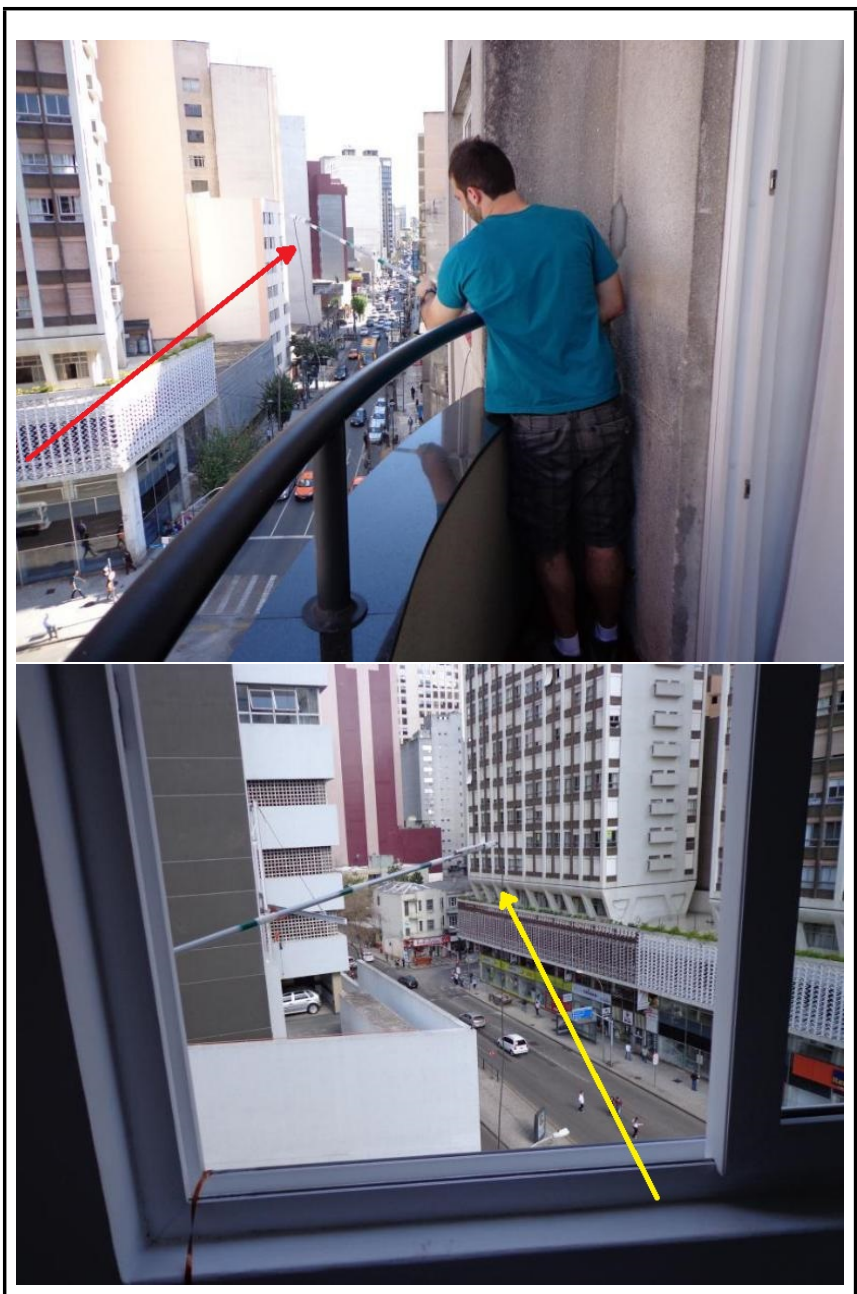

Figure 8. Use of a fishing rod to support the microphone during the measurements of facade 8 - external and internal views of the bedroom

classroom PG-06 was in compliance with the minimum acceptable limit recommended by the Portuguese standard (Brazilian standard cannot be used in this situation, since it covers exclusively bedrooms).

Although there were found small gaps between the glass panels, the classroom ha thick masonry walls $(25 \mathrm{~cm}$ thick) covered by a layer of a tile wall and thicker glasses than the situations shown before. This combination warranted higher sound insulation levels.

\subsection{Facade 7}

A weighted standardized level difference of $D_{l s, 2 m, n T, w}=29 \mathrm{~dB}$ was determined from this measurement. Thus, Facade 7 fell within the acceptable limit of $28 \mathrm{~dB}$ recommended by the European standard. ${ }^{13,18}$

The value of $D_{l s, 2 m, n T, w}=29 \mathrm{~dB}$ is attributed to good insulation presented by Facade 7. The stained glass panel was sealed hermetically against the masonry walls. The wooden 
door has a rubber bottom door seal that pressed against the floor of the foyer, providing water-tight acoustic and thermal insulation. In fact, it was difficult to pass the flat cable through the door to take this measurement. The door also had tetra key locks, which mitigated the effects of loss of sound insulation, since the two adjacent rooms were not exposed to direct openings, such as ordinary door locks.

\subsection{Table of Results}

Table 4 lists the values of weighted standardized level difference measured in each situation and compares them to the values stipulated by the Brazilian and Portuguese standards NBR 15.575-4 and RRAE, respectively.

Considering all the measurements and analyzing the data given in Table 4, one can see that the sound insulation of the facades of Brazilian buildings is not ideal. Approximately $77 \%$ of the studied cases (10 out of 13) failed to meet the minimum requirements established by the standards. The average value of the measured weighted standardized level difference was $22 \mathrm{~dB}$, which is lower than the minimum stablished by Portuguese and Brazilian standards for urban environments.

An analysis of the effects of the gaps left open intentionally proves that they could be perceived subjectively (i.e. there is a deterioration in the quality of sound insulation). Facades 4, 6, and 8 showed sound insulation losses of 2 to $3 \mathrm{~dB}$ according to the parameter $D_{2 m, n T, w}$, when openings were inserted. Facade 8, which was in compliance with NBR 15.575-4, became noncompliant with the minimum value when the acoustic window was not completely closed. In addition, the gaps affected more the sound insulation levels on high frequencies (1000 to $3150 \mathrm{~Hz}$ ), rather than on low frequencies. This suggested that sound insulation levels in this frequency range are especially sensitive to gaps of $0.5 \mathrm{~cm}$ order of magnitude.

Differences were found between the Brazilian construction model and that of developed countries. The latter used lighter materials in large-scale construction of walls and ceilings, and windows and doors that provide afford acoustic and thermal insulation. ${ }^{21-23}$

This finding points to systemic problems in Brazilian civil construction: the low quality of labor, the use of non-standard materials, the use of materials with unfavorable acoustic properties, the lack of maintenance and the unfamiliarity about the subject, which result in low quality buildings. Single layered glass windows are problematic for sound insulation, since glasses present a lower performance than brick walls, especially in the 500 to $1500 \mathrm{~Hz}$ frequency range. ${ }^{19}$ While masonry walls were built by an almost artisanal process (brick by brick), ensuring heavy buildings with high values of Rw, doors and windows were the weak link in the acoustic insulation of Brazilian buildings. ${ }^{23,24}$

\section{CONCLUSIONS}

The problem of environmental noise that affects Curitiba and other metropolises (not just in Brazil) has no single solution, but requires joint measures by society, scientists, and authorities. Noise emission levels must be reduced because imission levels (i.e., those that reach the receivers) must also be attenuated. In this context, the sound insulation of facades is an important measure to control noise pollution particularly in urban areas where traffic noise is responsible for environmental damage that deteriorates the quality of life.

Thirteen facades of different buildings in Curitiba were evaluated to determine their levels of sound insulation. The results of the measurements revealed that $77 \%$ of the analyzed facades are noncompliant with the Brazilian and Portuguese standards.

Openings of approximately $0.5 \mathrm{~cm}$ were left intentionally in two windows and a door to simulate the effect of gaps commonly found in Brazilian buildings. In the three situations, there was a decrease of 2 to $3 \mathrm{~dB}$ in the value of the parameter weighted standardized level difference $-D_{2 m, n T, w}$. The gap's effects on sound insulation levels in the 1000 to $3150 \mathrm{~Hz}$ frequency range is more significant than in the 100 to $1000 \mathrm{~Hz}$ frequency range.

The findings of this study are consistent with those of other researchers: Brazil has a systemic problem in the acoustic quality of its buildings. The main reasons are: imperfections in the finishing due to a poorly qualified workforce, lack of standardization of materials, lack of maintenance, and negligence or ignorance during the construction phase. Doors and windows are the weak link in the sound insulation of most buildings in Brazil.

There is no single action solution for this verified low sound insulation problem. The use of materials with higher acoustic performance, the training of qualified workforce, continuous maintenance, and the creation of awareness campaigns about noise directed to population are suggested as mitigation actions for this architectural and environmental issue.

\section{REFERENCES}

1 Pinto, F. A. C., Mardones, M. D. M. Noise mapping of densely populated neighborhoods example of Copacabana Rio de Janeiro Brazil. Environmental Monitoring Assessment, 155, 309-318, (2009). http://dx.doi.org/10.1007/s10661-008-0437-9

2 Bunn, F. Impacto ambiental sonoro no trecho Sul da Linha Verde na cidade de Curitiba (Environmental noise impact in the South segment of the Green Line in Curitiba), Graduate assignment in Environmental Engineering, Federal University of Paraná, Brazil, (2010).

3 Guedes, I. C. M.. Bertoli, S. R., and Zannin, P. H. T. Influence of urban shapes on environmental noise: a case study in Aracaju Brazil. Science of the Total Environment, 412, 66-76, (2011). http://dx.doi.org/10.1016/j.scitotenv.2011.10.018

${ }^{4}$ Engel, M. S. Caracterização da poluição sonora, através de medições e mapeamentos sonoros e entrevistas de percepção sonora na Linha Verde em Curitiba (Characterization of noise pollution based on measurements, noise mapping, and interviews on noise perception on the Green Line in Curitiba). Dissertation (Master's in Water Resources and Environmental Engineering), Federal University of Paraná, Brazil, (2012).

5 Zannin, P. H. T., Engel, M. S., Fiedler P. E. K., and Bunn F. Characterization of environmental noise based on noise measurements, noise mapping and interviews: A case study at a university campus in Brazil, Cities, 31, 317-327, (2012). http://dx.doi.org/10.1016/j.cities.2012.09.008

6 Bunn, F. Avaliação da Poluição Sonora Gerada Pelo Tráfego Ferroviário na Cidade de Curitiba (Assessment of Noise Pollution Generated By Rail Traffic in Curitiba). Dissertation (Master's in Water Resources and Environmental Engineering), Federal University of Paraná, Brazil, (2013). 
Table 4. Measured $D_{2 m, n T, w}$ values compared to the standards.

\begin{tabular}{|c|c|c|c|c|c|}
\hline CASE & FACADE & TYPE & $\begin{array}{l}\text { Measured } D_{2 m, n T, w}{ }^{*} \\
{[\mathrm{~dB}]}\end{array}$ & $\begin{array}{c}\text { Minimum } D_{2 m}, n T, w \\
\text { according to NBR 15.575-4[dB] }\end{array}$ & $\begin{array}{l}\text { Minimum } D_{2 m, n T, w} \\
\text { according to Portugal's RRAE [dB] }\end{array}$ \\
\hline 1 & 1 & bedroom & $23 \mathrm{I}$ & 25 & 28 \\
\hline 2 & 2 & bedroom & $22 \mathrm{I}$ & 25 & 28 \\
\hline 3 & 3 Situation 1 & bedroom & $17 \mathrm{I}$ & 25 & 28 \\
\hline 4 & 3 Situation 2 & bedroom & $9 \mathrm{I}$ & 25 & 28 \\
\hline 5 & 3 Situation 3 & bedroom & $19 \mathrm{I}$ & 25 & 28 \\
\hline 6 & 4 Situation 1 & living room & $26 \mathrm{I}$ & not specified & 28 \\
\hline 7 & 4 Situation 2 & living room & $24 \mathrm{I}$ & not specified & 28 \\
\hline 8 & 5 & classroom & $28 \mathrm{~S}$ & not specified & 28 \\
\hline 9 & 6 Situation 1 & bedroom & $21 \mathrm{I}$ & 25 & 28 \\
\hline 10 & 6 Situation 2 & bedroom & $18 \mathrm{I}$ & 25 & 28 \\
\hline 11 & 7 & living room & $29 \mathrm{~S}$ & not specified & 28 \\
\hline 12 & 8 Situation 1 & bedroom & $30 * *$ & 30 & 33 \\
\hline 13 & 8 Situation 2 & bedroom & $28 \mathrm{I}$ & 30 & 33 \\
\hline
\end{tabular}

SOURCES: Portugal (2008); ABNT (2013); the authors (2013)

*Values followed with the letter S are satisfactory; they meet the minimum requirements of the standards;

* Values followed with the letter I are insufficient; they do not meet the established requirements;

** Case 12 meets the Brazilian standard, but is noncompliant with the Portuguese standard.

7 Fiedler, P. E. K. Poluição sonora nos eixos estruturais de transporte da cidade de Curitiba PR (Noise pollution in the structural transport hubs of Curitiba, PR). Dissertation (Master's in Water Resources and Environmental Engineering), Federal University of Paraná, Brazil, (2013).

8 Jobim, M. S. S. Método de avaliação do nvel de satisfação dos clientes de imóveis residenciais (Method for assessing the level of satisfaction of residential real estate clients). Dissertation (Master's in Civil Engineering), Federal University of Rio Grande do Sul, Brazil, (1997).

9 Queiroz, C. S. and Viveiros, E. B. Simulação do desempenho do isolamento acústico de fachadas de edificações residenciais multifamiliares de diferentes perodos arquitetonicos (Simulation of the performance of sound insulation of façades of multifamily apartment buildings of different architectural periods). VI Congresso Iberoamericano de Acústica FIA 2008, Buenos Aires, Argentine, (2008).

10 Ferreira, J. A. C. and Zannin, P. H. T. Determinação de coeficientes de isolamento acústico: medições in situ e simulação computacional. Revista Ambiente Construdo, Porto Alegre, (2007).

11 Deutsches Institut f ur Normung. DIN 4.109: Schallschutz im Hochbau. Germany, (1989).

12 Associação Brasileira de Normas Técnicas (ABNT). (Brazilian Association of Technical Standards). NBR 15.575-4: Edificações habitacionais Desempenho Parte 4: Requisitos para os sistemas de vedações verticais internas e externas SVVIE [Residential Buildings Performance Part 4: Requirements for internal and external partition wall systems SVVIE]. Rio de Janeiro, (2013).

13 Portugal Presidência da República. Decreto do Presidente da República n. ${ }^{\circ}$ 34/2008. Diário da República, 1. ${ }^{a}$ Série N. ${ }^{\circ} 110-09$ de junho de 2008.

14 International Standard ISO 140-5 Acoustics Measurement of sound insulation in buildings and of building elements Part 5: Field measurements of airborne sound insulation of façade elements and façades. $2^{\text {nd }}$ Edition, (1998).

15 International Standard ISO 717-1 Acoustic Rating of sound insulation in buildings and of building elements Part 1: Airborne sound insulation. Geneva, (1996).
16 International Standard ISO 354 Measurement of sound absorption in a reverberation room. Geneva, (2003).

17 Brüel and Kjaer. Technical Documentation. Building Acoustics System. For Modular Precision Sound Analyzer Type 2260, (1996).

18 Portugal Ministério do Ambiente, do Ordenamento do Território e do Desenvolvimento Regional. Decreto Lei n. ${ }^{\circ}$

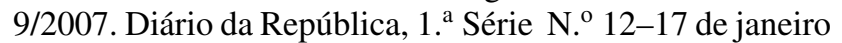
de 2007.

19 Bistafa, S. R. Acústica Aplicada ao Controle de Rudos [Acoustics Applied to Noise Control]. Ed. Edgard Blcher. São Paulo, (2006).

${ }^{20}$ Ferreira, J. A. C. Avaliação Acústica de Residtncias: Resultados Medidos e Simulados (Acoustic Assessment of Residences: Measured and Simulated Results). Dissertation (Master's in Mechanical Engineering), Federal University of Paraná, Brazil, 2004.

21 Bordeau, L. Sustainable development and the future of construction: a comparison of visions from various countries. Building Research \& Information, 27, 354-366, (1999). http://dx.doi.org/10.1080/096132199369183

22 Abiko, A. K., Gonçalves, O. M., and Cardoso, L. R. A. O futuro da construção civil no Brasil Resultados de um estudo de prospecção tecnológica da cadeia produtiva da construção habitacional (The Future of Construction in Brazil - Results of a technological study on the production chain of housing construction). São Paulo, (2003).

23 Zannin, P. H. T. and Ferreira, J. A. C. In situ performance of materials used in Brazilian building construction. Construction and Building Materials, 21, 1820-1824, (2007). http://dx.doi.org/10.1016/j.conbuildmat.2006.05.015

24 Polli, T. O. isolamento acústico comparado aos investimentos financeiros em edifcios multifamiliares de Florianópolis (Acoustic insulation compared to financial investments in multifamily buildings in Florianopolis). Dissertation (Master's in Architecture and Urbanism) Federal University of Santa Catarina, Brazil, (2007). 